\title{
BETWEEN SUPPORT AND SHAME: \\ THE IMPACTS OF WORKPLACE VIOLATIONS FOR IMMIGRANT FAMILIES
}

Shannon Gleeson

Immigration and Work

Research in the Sociology of Work, Volume 27, 29-52

Shannon Gleeson is Assistant Professor of Latin American and Latino Studies at the University of California, Santa Cruz. She completed her doctorate in Sociology and Demography from the University of California, Berkeley. Her research focuses on the workplace experiences of immigrants, the role of documentation status, and the legal mobilization processes. She is currently working on a book on the varying approaches to protecting workplace rights for Latino immigrants in San Jose, California and Houston, Texas. E-mail: sgleeson@ucsc.edu; Website: http://lals.ucsc.edu 


\begin{abstract}
Purpose - This study examines the conditions that lead to workplace violations for low-wage immigrant workers, and how family life shapes their decision to speak up. I also highlight how both employer abuse and the claims making process can impact individuals and their families.

Methodology/approach - This research adopts a mixed-method approach that includes a survey of 453 low-wage workers seeking pro bono legal assistance and 115 follow-up interviews with claimants. I also conduct a five-year ethnography of both a monthly state workshop provided for injured workers and a pro bono legal aid clinic in a predominantly Latino agricultural community on the California central coast.
\end{abstract}

Findings - Beyond the material effects of lost income, the stress of fighting for justice can have negative emotional impacts that intersect with complex family dynamics. While families can be an important source of support and inspiration during this time, the burden of the breadwinner can also temper workers' willingness to engage the labor standards enforcement system. Transnational obligations can further introduce a demobilizing dual frame of reference for workers who often hide their abuse from family members abroad who depend on them.

Research implications - Workplace abuse and the actual process of legal mobilization can have farreaching effects on the families of low-wage immigrant workers, suggesting the need for a more holistic understanding of the claims making experience.

Originality/value - This chapter tracks the challenges that workers face even once they have come forward to fight for their rights, and the multiple effects on families and children.

Keywords: Legal mobilization; workplace violation; family dynamics 
Introduction

Immigrant workers are a crucial part of the global economy. In the United States, 16 percent of workers are foreign-born, and an estimated 5.4 percent are undocumented (Batalova, 2011; Passel \& Cohn, 2009). Many of these workers are concentrated in low-wage industries where workplace violations are endemic, such as wage theft, unsafe work conditions, workplace injury, sexual harassment, and unjust terminations, and immigrant and undocumented workers are particularly at risk (Bernhardt et al., 2009). Federal and state laws often protect workers without regard to their immigration status, but conventional legal paradigms often overlook how workers are embedded in family units and broader communities, domestic, and transnational.

A broader perspective is needed to understand not only the ripple effect of economic precarity, but also the role that families play in shaping worker legal mobilization. Families comprise important information networks, provide linguistic brokering, and share resources to help facilitate claims, what I refer to as "claimsmaking," for workers in the wake of a workplace violation. For many, claimsmaking is a family affair, and parents, siblings, and even children often provide crucial support systems. However, family obligations can also influence whether and when aggrieved workers come forward to complain about abuses, and how far they will go to seek justice.

This research draws on a survey of 453 low-wage workers in the San Francisco Bay Area who have sought help from a legal aid clinic for a workplace violation, in between June 2010 and April 2012. My data also include follow-up interviews with 91 of these survey respondents, plus a supplementary sample of 24 injured workers. I further draw on ethnographic field notes from my work as a volunteer translator at a legal aid clinic located in an agricultural community on the California central coast. 
The chapter proceeds as follows. I begin by reviewing the literature on the feminization of immigration flows, the impacts of everyday deportability, and the challenges of immigrant worker mobilization. I then provide further details regarding the mixed methods approach for this study. My findings challenge the individualistic paradigms for conceptualizing workplace abuse and enforcing labor standards. I highlight the supportive function families play in helping immigrant workers find employment and providing assistance in the wake of workplace violations. I contrast this role with the difficult choices workers must make when deciding whether and how to fight for better working conditions. Ultimately, the negative fallout of both economic precarity and the legal bureaucracy impact claimants and those who depend on them, here and abroad.

Literature

The Feminization of Migration and Everyday Deportability

The traditional image of a single male migrating north is no longer the singular model of immigration. Increasingly, women are making the trek to the United States as well, with a current foreign-born male-to-female ratio of 95 (Migration Policy Institute, 2015), compared to 101 in 1997 (Schmidley \& Gibson, 1999). Half of male Mexican migrants (the largest immigrant nationality in the U.S.) travel alone, and women migrants tend to follow other family members (Cerrutti \& Massey, 2001). Each year immigrant workers send an estimated $\$ 48.4$ billion a year in remittances to their countries of origin (Congressional Budget Office, 2011). Immigrants are more likely to be married (55 percent, vs. 47 percent of native-born) (Brown \& Patten, 2014), and these migrants are often separated from spouses, children, and elderly dependents in their country of origin who depend on their support (Abrego, 2014; Donato, 2010; Zavella, 2011). This "feminization" of the immigration flow means that the context of 
reception for immigrants increasingly has far-reaching implications for families. Although 1 in 20 U.S. workers are undocumented, the immigration enforcement regime has a far broader impact on the families of these workers (Abrego \& Gleeson, 2013; Dreby, 2012). Forty-five percent of unauthorizedimmigrant households are couples with children, and of all children with at least one unauthorized parent, 79 percent were born in the United States (Passel \& Taylor, 2010). From another perspective, in 2010, over 9 million individuals were in families with at least one unauthorized adult and one U.S.-born child (Taylor, Lopez, Passel, \& Motel, 2011). Detention and deportation can devastate entire families, and the constant surveillance and fear of removal can discipline entire communities (Talavera, Nun ezMchiri, \& Heyman, 2010). This layers on top of economic disadvantage and workplace abuse to create multiplicative effects.

Migrant workers frequently follow in the paths of their pioneer friends and family members who then help them navigate local labor markets (Durand \& Massey, 2006; Smith, 2010). These job referrals help new workers find employment more easily than they might otherwise. Yet such strong ties are not always the most fruitful (Granovetter, 1973, 1995), and poor network ties can impact workers' ability to find a job that matches their skill set (Pastor \& Marcelli, 2000). Ethnic ties can be constraining and insufficient to lift immigrants out of poverty (Menjı́ var, 2000), and in many cases may funnel workers directly into exploitative contexts with little access to social mobility (Sanders \& Nee, 1987; Waldinger \& Lichter, 2003).

Friend and family connections are important for integrating immigrants into complex support bureaucracies that often lack sufficient staff and resources to assist linguistically and culturally diverse clienteles (e.g., Katz, 2014). As a result, non-English-speaking parents often rely on their children and other family members to act as linguistic and cultural brokers. Iconic examples include students translating between their immigrant parents and teachers and children accompanying parents to their 
medical appointments. Children can also be vital in mobilizing their parents to fight for their immigrant rights (Bloemraad \& Trost, 2008). However, this burden can be disruptive to family dynamics and challenge normative power relations between parents and children (Orellana, 2001; Reynolds \& Orellana, 2009).

\section{Worker Rights and Complicated Bureaucracies}

Foreign-born workers are nearly twice as likely to experience a minimum wage violation, especially foreign-born Latinos and undocumented women (Bernhardt et al., 2009). Latino immigrants also have the highest rates of occupational injuries, illnesses, and fatalities (Orrenius \& Zavodny, 2009), and undocumented workers experience particularly heightened exposure to numerous hazards (Hall \& Greenman, 2014). The high rates of poverty amongst Latinos are due not to lack of labor force participation, but rather the poor quality of jobs in which they are concentrated (Pastor, 2009, p. 24). Undocumented immigrants in particular are concentrated in positions that are exempt from statutory protections, such as small businesses or independent contracts.

Immigrants face distinct challenges to mobilizing their workplace rights, such as linguistic barriers and unfamiliarity with U.S. bureaucracies, and undocumented workers are further disadvantaged. While federal and state laws protect workers without regard to their immigration status, following the Supreme Court's 2002 Hoffman Plastics v. National Labor Relations Board decision, undocumented workers can face limited access to some of the most important remedies, such as reinstatement and backpay (Fisk \& Wishnie, 2005). Undocumented status can also discourage aggrieved workers from coming forward to file claims, not only due to fear of deportation, but also as a way to identify as a hard worker and accepted member of society (Gleeson, 2010). Even workers who know 
about their rights may be unwilling to demand them, for fear of being blacklisted or other retribution (Mireles, 2013).

Workplace abuse can impact men and women in distinct ways. Female migrant workers are more likely to face rampant sexual harassment, such as the epidemic of rape in agricultural fields (Bauer \& Ramirez, 2010). Financial need shifts how these women navigate these risks in their search for economic survival (Castaneda \& Zavella, 2003). Immigrant men face their own set of challenges. The labor force participation of immigrant mothers is lower than that of native-born mothers, but foreignand native-born fathers are working at very similar levels (Bureau of Labor Statistics, 2014). This means that these working fathers are also likely to be supporting relatively more dependents, especially stayat-home moms with young children (Cohany \& Sok, 2007).

Economic disadvantage can have far-reaching effects beyond monetary loss. Parents who feel that they are unable to support their families experience emotional distress and feelings of inadequacy. When women are unable to contribute income equally to the household, patriarchal expectations regarding the "second shift" are reinforced, thus cementing the disproportionate burden of reproductive labor on women (Cohen, 2004; Zavella, 1987). Women experiencing intimate partner abuse are particularly vulnerable if they have few economic alternatives to support themselves and their children (e.g., Alcalde, 2010; Berger, 2009; Edelson, Hokoda, \& Ramos-Lira, 2007; Mattson \& Ruiz, 2005; Villalon, 2010).

In this chapter I examine how the experience of workplace violation impacts workers' family lives, how families support workers through the process of fighting for their rights, and how workers weigh their obligation to their family against the goal of seeking justice. 


\section{Methodology}

This study examines the experiences of low-wage workers who have experienced workplace abuse and decided to come forward to seek restitution. I draw on a survey of 453 workers seeking pro bono legal assistance for a range of claims, such as wage theft, unjust termination, sexual harassment, and workplace injury. I examine the conditions that lead to these workplace violations, and the resources and challenges immigrant workers in particular confront when making claims on their rights. Surveys were conducted from June 2010 through April 2012, at four workers' rights clinics in the San Francisco Bay Area. Interviews with 91 workers 12-30 months following their initial survey also provide insight into the experience workers had over the course of their claim.

In this chapter, I focus especially on the 73 percent of respondents who are foreign-born (331).

Of those, 27 percent identify as citizens ( $N=89), 22$ percent as legal permanent residents $(N=72)$, and 51 percent $(\mathrm{N}=170)$ are estimated to be undocumented. As Table 1 confirms, this distribution is consistent with the sample of workers who were later interviewed. The survey sample reveals that while 77 percent of native-born claimants were married, only 52 percent had children. The opposite is true of foreign-born respondents. Forty-four percent of immigrant respondents were married, 77 percent of whom had children. The children of undocumented respondents were most likely to be school-aged, and a third of undocumented respondents with children had dependent children who lived in their country of origin.

Additionally, I draw on a five-year study of occupational injury, through ongoing ethnographic observations of the monthly California Division of Workers' Compensation Injured Workers Workshop, where I listened to workers describe their problems and requests for assistance. From this setting, I also interviewed 24 injured workers regarding their experience in navigating the workers' compensation 
system. My experience as a volunteer legal interviewer for a small law clinic in a rural farmworker community on the central coast of California also inform these findings. Through

Insert Table 1 Here

these data, I examine the conditions that gave rise to workplace abuse, the factors shaping when and how workers reported their violation, and how this journey affected workers and their families.

Findings

\section{Balancing Family Life and Navigating Power at Work}

Low-wage workers struggle to balance family obligations with their job requirements. Few of the workers I interviewed had the power and autonomy that professionals like myself take for granted. For example, Melita, a Peruvian childcare worker was fired from her job for failing to fill out the appropriate vacation request forms to attend her daughter's graduation from UCLA. She was subsequently fired. Similarly, Juana, a housekeeper at a large hospital, hastily arranged to attend her father's funeral. He died on a Wednesday, and Juana asked for only one additional day off outside her regularly scheduled time, in order to travel to Mexico to make arrangements. Like Melita, she was fired on the technicality of failing to follow protocol, even though she had spoken with the office secretary, and her daughter called to confirm her mother's plans. For workers like Juana, the lack of flexibility afforded by their employers in these emergency situations exacerbate the ongoing stressors of everyday 
family life. Juana's termination came during a stressful period, which included her son's deployment to Afghanistan and a lengthy divorce. Though she was protected by a union, after her union lost their contract, she had no recourse as an at-will employee. She subsequently went from an hourly pay rate of $\$ 23$ with benefits to earning $\$ 10.50$ at her new position at a non-unionized hotel. To make ends meet she works a grueling schedule from 5 am to $1 \mathrm{pm}$ at the hospital, followed by another janitorial position from $3 \mathrm{pm}$ to $11 \mathrm{pm}$. She ultimately lost her home, unable to qualify for a loan modification.

Although federal and state law protects key aspects of family life, such as through the Family and Medical Leave Act (Albiston, 2010), the structural position of many low-wage immigrant workers, almost all of whom are at-will employees, leaves them unprotected in practice. For example, Consuelo, an undocumented mother, worked as a subcontracted janitor. She endured chronic wage theft, verbal abuse, and her supervisor refused to provide basic accommodations when she was pregnant. She rarely complained and continued in this position because she needed the money. She had her own child to support, as well as a niece she now cares for after her sister returned to Mexico. After a year with the company, Consuelo recounts how she was eventually fired. "He (her crew leader) asked, 'are you pregnant?' I said yes ... I was only three months along. He responded, 'you better just come back when you are done.'" In this tacit threat, Consuelo's employer suggested that she had to choose. "Either end your pregnancy or end your job." Consuelo took the case to the state discrimination agency, and sought legal assistance. However, because the small company had only five employees and was not covered by law, Consuelo was told she had no recourse. Because she was undocumented, she felt that her ability to demand reinstatement was also very tenuous.

Employers are aware of workers' obligations, and may also exploit family relationships in order to exact retribution. Though some statutes protect workers from employer retaliation (e.g., Equal Employment Opportunity Commission, 2014), these remedies are difficult to prove and pursue. For 
example, farmworkers regularly recounted being fearful that their entire family would be blacklisted by field subcontractors who avoided hiring "troublemakers." Those workers who complained about unpaid wages, lack of water and toilets, or who reported injuries, may not be hired back the following season, and neither would their family members. For undocumented workers in particular, prompting employer retaliations posed a risk not only to individual workers, but also to any other family members who work for the same employer. Such was the case for Jordi, an undocumented Salvadoran cook whose cousin was fired soon after he filed a formal complaint. "When they received that card (from the Labor Commissioner), bam, they fired my cousin. Because of me, what a shame, they fired him ... and told him that they just didn't have any more work available ... He didn't say anything, since he really had just started."

In other cases, employers may exploit family ties to exact retribution. This was the dramatic case of a berry picker, who had filed a simple request for medical attention following a painful bug bite. Rather than address the worker's concern, this woman's supervisor constructed an elaborate story to claim that the bite was indeed evidence of a love affair. Threatening to expose her invented infidelity to her husband, the supervisor demanded that the worker drop her claim, which she did. However, when the bite soon after developed into a painful rash, and she asked again for medical attention, the worker was ultimately terminated. As the bite worsened, this worker pursued her claim independently with the help of the legal aid clinic. This unsurprisingly enraged her supervisor, who in response made true on her threat and called her husband.

Other workers described similar tensions with family members prompted by the circumstances of workplace abuse. Susana had been a bedrock to her sister, and is the one that led the sexual harassment charge against her employer. Yet, at home she kept the ordeal a secret from her husband, for fear of what he would do. "I knew he wouldn't just stand by and let it happen. And when he found 
out, he was very upset with me. In fact, today we got in a fight about it again. He says, 'why didn't I tell him,' but honestly, I felt stuck in the middle. Either I tell him, and he marches up to the company and 'takes care of it,' and I'm now lost without a job and a husband who has landed in jail. Or, I stay quiet." For both women, negotiating family relationships in the U.S. or abroad became an important aspect of pursuing workplace justice. While in some cases family members provided crucial support, the practical requirements of claimsmaking, and the shame associated with sexual harassment in particular, fostered feelings of secrecy and distrust.

\section{Family Solidarity in Fighting for Justice}

Research has long documented the importance that social networks play in the lives of immigrant workers. To be sure, workers rely on family members for both moral and material support. Workers frequently recounted the importance of their family's aid throughout the process of fighting workplace abuse. For example, Alonso, a prep cook at a popular restaurant explains how his mother's influence encouraged him to speak up after he developed a hernia at work. "I (spoke up) because I get it from my upbringing from my mom ... it's essential to know that you have rights, that you can do things, and that you don't have to be fearful of others."

Families also provided information about where to go for help. Whereas 16 percent of nativeborn respondents heard about the workers' rights clinic from a friend or family member, this is true for 31 percent of the foreign-born (and 40 percent of the undocumented). For example, Angelina, an undocumented single mother, worked at a warehouse with her sister, where their supervisor would regularly "expose himself, stand in the scaffolding above and drop his pants, or just walk by and fondle his genitals in front of us." Though Angelina was initially reluctant to come forward, she eventually 
followed her sister's lead. "My sister and I started to talk about it ... we decided to look for help. We didn't complain to the company, but looked for other help." After hearing about the workers' rights clinic on the Internet and the radio, they made an appointment.

Older workers often turned to their adult children for assistance, who in turn helped their immigrant parents tap into their wider social networks. Ramon, a ground manager for an apartment building was fired he felt, unjustly - after nearly 21 years of service. He learned about the legal aid clinic from the sister of his daughter's boyfriend, who was attending a nearby university. "He told me to go there, and what to do." For limited English proficient workers, and those unfamiliar with the U.S. bureaucracy, family members were crucial assets for filling out government forms, for translating correspondence from employers, doctors, and insurance systems, and accompanying workers to meetings where no bilingual staff were made available. Clients who spoke indigenous languages often had to rely exclusively on their family members as their lifeline of communication.

Many of the immigrant women I spoke to described gendered systems of mutual support, which helped them endure abuse where there were no other alternatives. This was true for undocumented family members in particularly, who, despite egregious abuses, had few other options and were strengthened by each other's solidarity. For example, Magdalena and her sister worked minimum wage for a janitorial contractor, while attending college during the day. Despite putting in night shifts from 6 pm to midnight, six days a week, the women were regularly only paid for three hours a night. When they complained, they were told to accept the terms of pay, or they would be fired, given that "there are many workers willing to do this work if you are not." In a down economy, with few alternative job prospects that could accommodate her schedule, Magdalena and her sister endured at this job for over three years until another opportunity crossed their path. 
In other cases, workers recounted speaking up specifically out of a desire to protect their family members. One undocumented college student and her sister worked as temporary employees for a local well-known restaurant. She recounted a high-pressure work environment, repeated verbal abuse from management, and differential treatment compared to the restaurant's permanent - and mostly white employees. Her sister was quiet and rarely spoke up. Belinda felt an obligation to protect her, and would regularly speak up on their behalf, drawing the ire of management. However, this courage also has its limits. One evening, Belinda was groped by two drunk male customers who followed her into the restroom. She immediately reported the incident to her manager, who characteristically did nothing in response, having branded Belinda a troublemaker. Fearing for her safety and especially that of her softspoken sister, Belinda and her sister simply quit.

\section{Family Obligations and Weighing a Claim}

Although families can play an important supportive role for immigrant workers, workers also heavily weigh their decision to speak up against their sense of obligation to these same family members. For workers like Jose Luis, an undocumented restaurant worker from Oaxaca, job was a lifeline for his entire family unit. He explained the reasons he journeyed north for work. "I asked (my brother) how the jobs were, and he said it was ok, that yes, there were jobs, and that if I just worked hard, I could do it." Jose Luis started in a small factory that employed 15 workers or so, and after about a year went to work in a restaurant. "I earned about $\$ 2100$ a month, and well, it was enough to get by, to go out and buy things and food, and have something to send home to your family." As the youngest, and only unmarried, of 10 siblings, his devotion to his mother was a driving factor when he considered whether to complain about his unsafe work conditions and erratic scheduling. When he lost his second job, Jose was left with only a 
few shifts at McDonalds, picking up all the extra hours he could. So, in this context, unsafe work conditions were a secondary concern.

Workers who were the primary breadwinners for their household felt a particularly heavy burden in a region with some of the highest housing costs in the nation. Juan Carlos, a driver who suffered a back injury while unloading his truck, explains why he ignored even the counsel of his coworkers who urged him to take it easy and seek medical care for his injuries. "They told me, don't be stupid, quit my job, but, no, I had to pay my bills, my house, my car, I couldn't just leave my job. So I continued to work 12 to 14 hour days." He eventually separated from his wife due to the stress. Even the increased perception of deportation meant that workers may delay coming forward, as was the case with an undocumented masero in a tortilla factory, whose wife also worked on the line. He had previously joined a group of workers to demand a raise, but quickly backed off when lead organizers were fired under the pretense of a looming employer immigration audit. He regularly worked overtime without additional pay, had been injured on numerous occasions without medical attention, and was nearly numb to the constant verbal abuse. Yet, he was reluctant to pursue formal claims for his unpaid wages or injuries, fearing for the fate for both he and his wife, and their ability to provide for their young children.

Workers also had to weigh their spouse's workplace woes, which could be far more dire than their own. For example, Macarena was unemployed following a near fatal crash en route to her job at a discount retailer where she had worked for seven years. She spent three days in coma, three months in a hospital, and three months more recovering at home. Despite being told she would have a job waiting when she recovered, she was eventually let go. Her partner, a landscaper who worked long hours hesitated to go to the Labor Commissioner to demand his unpaid overtime. With Macarena's declining health, he could not risk losing his job, although he also sorely needed to recover his lost income. Both 
Macarena and her partner were undocumented, making his wages the only viable source of support for the family.

Even after filing a claim, many workers continue in their positions despite continued abuse from their employers. For example, Mariana explained why she continues to work for a popular ethnic grocer, despite the constant verbal abuse and retribution she had to endure from her spiteful manager. As 1 of 10 siblings, and the only one living in the United States, Mariana feels tremendous pressure to keep her job. While she feels that she could likely get a job elsewhere, she stays because she also values the store's standard practice of permitting workers to take a month (unpaid) vacation during the holidays. Mariana desperately wants to visit her family in Mexico, although her pending U-Visa application, chronic illness, and finances have kept her from actually doing so. She and her children also benefit from the health insurance the store provides. Nonetheless, these benefits trump the long hours, low pay, and other harassment she endures.

In other cases, I found some workers who may have initiated a claim, but chose not to pursue it because of the time it would have taken them away from their job and family. I spoke with Lino, an undocumented Mexican who had been in the U.S. for about a decade and who worked as part of a small tree service. He did everything from truck driving, to working the chipper, and clearing brush. He had been injured, cheated of his promised wages, and the Chicano owners would constantly lodge insults at Lino and his co-workers, calling them frijoleros/beaners, perritos/doggies, mojados/wetbacks, or simply, pinche mexicanos/fucking Mexicans. When one ambitious worker managed to rally his fellow full-time permanent staff to complain, they were immediately fired, including Lino. Immediately thereafter, the tree service completely shut down, in an attempt to avoid paying the wage settlement. While the other indignant workers pursued their claim and won, Lino chose not to. It all came down to time, he explained. He simply did not have time to attend the appointments necessary to move his individual 
claim forward. He was still crawling out of debt he accumulated during the six weeks he was left without a job. He had borrowed money extensively to carry him through this bout of unemployment, and had a wife and two small children (ages three and six) to support. While he liked his new boss, Lino feared that he might discover his previous claim, and brand him a troublemaker. When I asked Lino if he wanted to reopen his case, given his co-workers' success, and since he was still well within the statute of limitations to do so, he was ambivalent. He contrasted his situation to his co-workers, who had ultimately returned to Mexico. Unlike them, Lino had chosen to remain in the United States with his family, and hence still had a lot to lose.

\section{Long-Term Impacts of Workplace Violations on Families Here and There}

The economic and emotional impacts of workplace abuse, and the arduous process of fighting for one's rights, can compound the everyday challenges of family life. On the economic end, lost income can be devastating for families already living a precarious existence. For example, Yadira, a unionized janitor earning $\$ 9 /$ hour, was never given her union-negotiated $\$ 12 /$ hour contract wage, and had not received any raises in her four years of service. When she complained, she was ultimately fired, on the pretense of unauthorized use of company equipment, a claim she denies. To make matters worse, soon after she lost her job, Yadira's son was shot in the head by gang member, forcing her family to move to a safer, and more expensive neighborhood to avoid further retaliation. Her rent went from $\$ 950$ to $\$ 1500 /$ month. "I used my last check to pay rent, and then my (three) other brothers loaned me money little by little. But, it was so traumatic, I felt very bad, where was I going to ask for help? And what was more, we had other problems at home." After two months of searching, Yadira eventually found a lower paid non-union position through her husband's cousin. She has been there for two years without a raise, but appreciates the flexibility he allows her. Finances remain tight, as she is the sole earner for her disabled husband and five children. Legally, she has no right to get her job back. 
While the process of filing a legal claim can bring some restitution, workers' attempts to negotiate demands at work can permanently stress family relationships. Joaquín, a skilled welder explained the circumstances that eventually led to his family separation. "I had been at that company for seven years, I had paid vacation, I had paid bonuses at the end of the year ... I dedicated so many years, many hours to that company, and was even on the brink of losing my son (for it)." The long hours he was forced to work meant time away from his growing children and wife. After he became injured and was soon thereafter fired, Joaquin his wife and children were forced to move in with family hundreds of miles away in another part of the state. Losing both his job and his family has taken an emotional toll. "Since I stopped working, everything has changed for me, my life, family, economic state. It's affected me ... there are moments when I am depressed, I get angry easily, but I'm taking medication to deal with it, because I can't handle it anymore. I can't live without that pill. I have to take it every day. But I'm telling you, before (this injury), I didn't live this way."

Jonatan, another injured truck driver, describes the effect his injury has had on his marriage. "I've had problems with my wife ... I'm stressed, irritated, in a bad mood. All of that, the whole world notices." Before losing his job, Jonata'n earned \$27/hour at a company where he had worked 17 years. He would also often pick up additional deliveries to earn extra cash. But by the time I spoke with him, the years of prosperity were far behind him. After suffering a back injury, he was unable to find work, was struggling with the workers' compensation insurance company, and his disability payments were running out. "I keep looking for work and sending the reports they ask for. In the month and a half to come, I will run out of money and my savings, because my costs are serious, house payments, I have four kids .... insurance, cars ... daily costs, food, electricity, water, all of that, next month, I don't know how I'm going to do it." Unauthorized injured workers face particular challenges when they lose their job. They do not qualify for federal unemployment benefits, and only qualify for state disability if they 
have paid into the system (Legal Aid Society Employment Law Center, 2012). Pancho, an undocumented metalworker with a back injury, recounts the multiplicative effect his injury had on his family. "It is difficult to live without papers. I've been here 15 years; I have two sons born here, 5 and 10 .... So I would say it's desperate to be here without papers, no driver's license, tried to find a job, and now even worse, injured."

For some injured workers, the impact is far more than economic, and also affects their very identity as a parent. Marta, an injured fieldworker and single mother explained how her back injury impacted her ability to care for her children. Strapped for cash, she also lamented her basic inability to use her hands to cook. "I had always cooked for the house ... my son would say 'I'm hungry,' and you may not believe it, but I couldn't even cut a chicken, I couldn't be on my feet ....it was very frustrating." Ashamed, she also admitted that out of frustration she would scold her children who were insistent. Concurrently navigating an abusive marriage, she eventually found someone to help her cook, despite enduring scorn from other mothers. "That was a dark time ... that I wouldn't wish on anyone," she implored. Similarly, Berta, an undocumented mother who was fired after complaining about her manager's constant verbal harassment, described how the ordeal compounded her existing troubles. Already suffering from depression, and struggling with an alcoholic husband, her mental health deteriorated further. The abuse and the arduous process of finding a new job, seeking public assistance to sustain her family, and dealing with the requirements that the public bureaucracy demanded were overwhelming. Many Latina immigrants like Marta and Berta lack access to mental health services, which can lead to debilitating effects in work and family life (Organista \& Snowden, 2003). Their plight goes largely unnoticed.

Even for workers who are in the U.S. alone, financial obligations to support families in their country of origin can weigh heavy. Octavio, an undocumented Peruvian truck driver, worried constantly 
about how to support his family back home. Seventy-six percent of undocumented respondents like him sent money home to their country of origin, compared to only 45 percent of foreign-born U.S. citizens. During his three years of working 60 hours a week delivering seafood, Octavio had complained about broken equipment numerous times. Each time something happened, he was told to simply "be more careful." One day he slipped and fell while loading a truck, injuring his knee and shoulder. At first, he doubted the gravity of the injury, but reported it nonetheless to his supervisor as he was trained to do. The supervisor directed him to finish his route, as there were no other drivers available. "Since I had done it a bunch of times ... like when I was sick with the flu, (I was always told) 'you can do it, you can do it'... It was normal." Octavio's family obligations led him push to through his pain. "The whole world knows that you need to work, that you need to send money to your family." He continued working until the pain became too severe. When he finally went to file a claim, the human resources department delayed sending Octavio to the hospital. When he ultimately visited the assigned occupational health clinic, they dismissed his claim. A year later, he has struggled with the workers' compensation system, is running out of disability payments, and is unable to return to work. He fears that he will no longer be able to afford to send $\$ 1000 \$ 1200$ to Mexico to support his children's university education. "While I was working, it was no problem ... So for me it is very hard ... Even though I don't have family here, my economic obligations to my kids are strong .... Since I got injured, I practically don't sleep."

The obligations immigrant workers have to their families can extend to complex family structures in which their current economic struggles in the U.S. matter less than the comparative disadvantage of their relatives back home. Berta struggles to balance her obligations to her own children, as well as her husband's parents, to whom she also feels responsible. "They live in Mexico, but nonetheless, since we're the only ones who are over here ... I send them money." Her alcoholic husband does not consistently send support, so it falls on Berta to do so. These obligations, on top of having to 
battle the food stamps office she's relied on since losing her job has been difficult. "Imagine, you're depressed, you get a bill, you think, Oh God, I want to kill myself." And in fact, Berta did attempt suicide, and spent time recuperating in the hospital. "So now all these problems at work come to me as a mountain, and I've never felt more isolated ... I would ask God, what am I going to do? I would cry, I wouldn't go out, and my kids (were affected). I think that when I got depressed, the whole house did too." Consuelo similarly recounted her regret at not being able to help grandmother with medical bills for cancer treatment after she was fired. "It affected me considerably ... I was the one that sent her money to help her survive, and when I stopped working, her cancer advanced because I didn't send her money for the medicine. That affected me so much, and affected my pregnancy because of how depressed I became. I was so depressed that I couldn't send my grandmother money, and she died."

Wrangling with workplace problems was stressful enough for workers, but navigating labor standards enforcement bureaucracies also had deleterious effects on respondents and their family lives. Juanes, the only son of a family of eight children, discussed how his injury, the workers' compensation claim he attempted to file, and ultimately losing his job, impacted his ability to be with his mother during her final days. "I was at the Oakland airport like at 10pm, I had my phone and a calling card, I tried to call. I had been talking with my sister ... they kept telling my mom 'Just hold on, Juanes is coming'... the doctor had already said there was no cure ... she kept opening her eyes looking for me." Because he had to comply with the various requirements for his case, Juanes had delayed his trip home too long, and never made it in time to say goodbye.

Some workers had their family lives completely transformed by the abuse they faced at work, and the complicated requirements of filing and sustaining a claim. For example, Gloria, an undocumented single mother from Mexico City, was sexually assaulted by a male supervisor at the union maintenance job where she worked. As a lesbian, she experienced constant harassment, but 
otherwise valued this unionized $\$ 15 /$ hour job, which she described as a "godsend" after losing her previous job for taking time off following the death of her mother. Gloria had endured unwanted groping for four months until she finally spoke up and alerted her supervisors. When they dismissed her accusations, her therapist encouraged her to talk to the police. She recorded her manager's improprieties, and took the evidence to the police, who quickly identified the aggressor in a database of offenders. He was swiftly arrested and convicted, yet Gloria was fired and left only with the option of filing a workers' compensation claim for the psychological distress she had endured.

In order to receive her benefits, Gloria was declared disabled, and unable to simultaneously return to work. She also had to see an insurance appointed psychiatrist, who spoke no Spanish and insisted she take medication instead of providing talk therapy. After a grueling process that required hours of depositions, her claim ultimately produced a $\$ 15,000$ settlement, which quickly dried up after a year of paying debts and supporting her family. Gloria ultimately lost her apartment, separated from her partner, and with no other income to rely on, she reluctantly moved in with friends, during which time her son was sexually molested. She unequivocally blamed herself. Emotionally distressed, Gloria detailed a litany of ripple effects that her assault and the subsequent claims making process had on her family.

They didn't give me my job back (as promised) ... I was the victim in this case, they took my job ... this man went to jail, I filmed it, took all the proof to the police, everything was proven ... and now, I wonder, why did I speak up? I ended up without a job, I ended up in all sorts of problems, so now I wonder, why did I speak up? I should have stayed quiet, I would have kept my job, my economic state would have been better, because that was a good job ... My son's rapist went to jail and is now out. My aggressor went to jail and is now out. But I am left here, with nothing. 
As a crime victim, Gloria was eligible for a U-Visa. However, during this time of extreme stress and poverty, Gloria took desperate measures to support her family and was convicted of petty theft, thus jeopardizing her visa application. She now relies mostly on a modest amount of child support, food assistance, and odd jobs. Her younger son is doing better now, but not great. Her older son, who is undocumented and does not qualify for the Deferred Action for Childhood Arrivals (DACA) program, left college to help out financially. Gloria's family in Mexico calls often, but she is ashamed to share her story. "I don't tell them what I'm going through. They think I have it good, that I live in the U.S., and that everything is great. But I can't bring myself to tell them anything." For workers like Gloria, the impact of workplace abuse was far-reaching, leaving her with a cautionary tale about the benefits and costs of claimsmaking. Obligated to both her children in the U.S. and her family in Mexico, she assured me that she would have been better off saying nothing.

\section{Conclusion}

In this chapter, I have offered a broader look into the impact of workplace violations and the process of seeking restitution for workers and their families. These findings demonstrate that workplace abuse (which at times may be deemed wholly legal by the law) can affect far more than the individual workers at whom they are targeted. Workers struggle to balance workplace demands with family life, and employers may exploit family relationships in efforts to control workers. When issues arise, workers often rely on their family for support, yet must consider their obligation to these same family members when considering the time and opportunity costs of filing a claim. For undocumented workers, the 
looming specter of deportation, and the prohibition against authorized work, raises the stakes of employer retaliation.

The demands of family life fall heavy on women workers who are mothers, but also men who feel the weight of being the primary breadwinner. Basic obligations such as childcare and elder care must be delicately managed, and major life changes such as deaths, divorces, and pregnancy can create particular stress. These economic and emotional tensions impact families living in the United States, as well as transnational immigrant families who rely on remittances and may poorly understand the challenges their migrant loved ones are facing. In some instances, aggrieved immigrant workers may turn to their family for support. Yet in others, they may feel shame for failing to prosper, and wish instead to protect their families from the burdens they face.

Predominant paradigms of low-wage work tend to focus on the dyadic relationships between employers and workers. However, worker protections and outreach strategies must acknowledge the families and communities in which workers are embedded, and the far-reaching impact of workplace abuse. Existing protections such as the Family and Medical Leave Act are insufficiently enforced, and is near non-existent for precarious workers, those in temporary and contract positions, and especially those who are undocumented. For those lacking legal status, unjust terminations after complaining about wage theft, sexual harassment, or unsafe work conditions are a costly risk. In a claims-driven system, the burden of initiating enforcement falls to workers who bear the brunt of employer retaliation that often follows. The fear of deportation is real, but just as important are the consequences of being fired. Limited remedies for backpay and reinstatement, and blocked access to most social safety net programs for undocumented workers raise the stakes.

Future research in immigrant incorporation must continue to identify how the various arenas of immigrant life intersect. The typically individualized models for economic integration must cast a wider 
gaze to understand how economic precarity impacts family life. Labor scholars should also critically examine how families both support and complicate immigrant workers' abilities to make claims on their rights. In an era in which remittances play an increasing share of household income in traditional sending countries, binational models of workers' rights enforcement deserve greater attention as well. 
Notes

1. While Hoffman was focused on the context of the National Labor Relations Act, over the last decade, there have been ongoing challenges in the courts that leave the rights of undocumented workers unsettled. The State of California has inscribed the rights of undocumented workers in Labor Code 1171.5, and recently passed additional protections against employer retaliations (National Employment Law Project, 2013). However, the actual implementation of these protections remain to be seen.

2. Respondents were incentivized with a \$15 gift card for their participation.

3. Interview, $9 / 11 / 13$

4. Interview, 9/21/13.

5. Interview, 10/21/11.

6. Interview, 12/12/11.

7. Interview, 10/8/13.

8. Interview, 10/8/13.

9. Interview, 3/3/09.

10. Interview, $1 / 9 / 14$.

11. Interview, 10/8/13.

12. Interview, 12/20/11.

13. Interview, 5/21/14.

14. Interview, 5/14/14.

15. Interview, 3/5/09. 
16. The California minimum hourly wage at the time of this research was $\$ 8.00$, and rose to $\$ 9.00$ in 2014. In contrast, the living wage for a single adult is currently $\$ 12.83$ in San Francisco, $\$ 12.01$ in San Jose, and \$11.51 in Oakland, CA. Available at http://livingwage.mit.edu/

17. Interview, 10/9/09.

18. Interview, 4/8/14.

19. Interview, 9/23/13.

20. Interview, 12/20/11.

21. Interview, 11/22/13.

22. Interview, 6/6/13.

23. Interview, $7 / 29 / 09$.

24. Interview, 7/17/09.

25. Interview, 7/17/09.

26. Interview, 2/28/09.

27. Interview, 12/12/11.

28. Interview, 2/13/09.

29. Interview, $1 / 24 / 12$.

30. Interview, 10/3/13. 


\section{Acknowledgements}

The author acknowledges helpful discussion during the UC Wide Immigration Conference, We Asked for Workers and Families Came: Children, Youth, and Families In Migration (University of California-Los Angeles, 2/22/13), and feedback provided by Patricia Zavella and an anonymous reviewer. The author also acknowledges funding support from the University of California Institute for Mexico and the United States (UC MEXUS), the UC Global Health Institute Center of Expertise in Migration and Health, the UC Center for New Racial Studies, the UC Santa Cruz Committee on Research (COR) Faculty Research Grant, and the UCSC Chicano/Latino Research Center. 
References

Abrego, L. (2014). Sacrificing families: Navigating laws, labor, and love across borders. Stanford, CA: Stanford University Press.

Abrego, L., \& Gleeson, S. (2013). Immigration policies hurt immigrant families more than they help. In T. Payan \& E. de la Garza (Eds.), Working Paper in Immigration Reform: A System for the 21st Century. Rice University Baker Institute's Latin America Initiative Immigration Research Project.

Albiston, C. R. (2010). Institutional inequality and the mobilization of the family and medical leave act: Rights on leave. New York, NY: Cambridge University Press.

Alcalde, M. C. (2010). Violence across borders: Familism, hegemonic masculinity, and self-sacrificing femininity in the lives of Mexican and Peruvian migrants. Latino Studies, 8(1), 48-68.

Batalova, J. (2011). Foreign-born wage and salary workers in the US labor force and unions. Washington, DC: Migration Policy Institute. Retrieved from http://www.migrationinformation.org/usfocus/display.cfm?ID=855\#3

Bauer, M., \& Ramı'rez, M. (2010). Injustice on our plates: Immigrant women in the U.S. food industry. Southern Poverty Law Center. Retrieved from http://www.splcenter.org/getinformed/publications/injustice-on-our-plates

Berger, S. (2009). (Un)worthy: Latina battered immigrants under VAWA and the construction of neoliberal subjects. Citizenship Studies, 13(3), 201-217.

Bernhardt, A., Milkman, R., Theodore, N., Heckathorn, D., Auer, M., DeFilippis, J., \& Gonzalez, A. L. (2009). Broken laws, unprotected workers: Violations of employment and labor laws in America's 
cities. Center for Urban Economic Development, National Employment Law Project, and the UCLA Institute for Research on Labor and Employment. Retrieved from http://nelp.3cdn.net/319982941a5496c741_9qm6b92kg.pdf

Bloemraad, I., \& Trost, C. (2008). It's a family affair: Intergenerational mobilization in the spring 2006 protests. American Behavioral Scientist, 52(4), 507-507.

Brown, A., \& Patten, E. (2014). Statistical portrait of the foreign-born population in the United States, 2012. Washington, DC: Pew Research Hispanic Trends Project. Retrieved from http://www.pewhispanic.org/2014/04/29/statistical-portrait-of-the-foreign-born-populationinthe-united-states-2012/

Bureau of Labor Statistics. (2014). Labor force characteristics of foreign-born workers summary. Economic News Release. Retrieved from http://www.bls.gov/news.release/forbrn.nr0.htm

Castaneda, X., \& Zavella, P. (2003). Changing constructions of sexuality and risk: Migrant Mexican women farmworkers in California. Journal of Latin American Anthropology, 8(2), 126-150.

Cerrutti, M., \& Massey, D. S. (2001). On the auspices of female migration from Mexico to the United States. Demography, 38(2), 187-200.

Cohany, S. R., \& Sok, E. (2007). Married mothers in the labor force: Trends in labor force participation of married mothers of infants. Monthly Labor Review. Retrieved from http://www.bls.gov/opub/mlr/2007/02/art2full.pdf

Cohen, P. N. (2004). The gender division of labor: 'Keeping house' and occupational segregation in the United States. Gender and Society, 18, 239-252. 
Congressional Budget Office. (2011). Migrants' remittances and related economic flows. Retrieved from http://www.cbo.gov/sites/default/files/cbofiles/ftpdocs/120xx/doc12053/0224remittances cha rtbook.pdf

Donato, K. M. (2010). U.S. migration from Latin America: Gendered patterns and shifts. The ANNALS of the American Academy of Political and Social Science, 630(1) (July 1), 78-92.

Dreby, J. (2012). How today's immigration enforcement policies impact children, families, and communities: A view from the ground. Washington, DC: Center for American Progress. Retrieved from http://www.americanprogress.org/wpcontent/uploads/2012/08/DrebyImmigrationFamiliesFINAL.pdf

Durand, J., \& Massey, D. S. (2006). Crossing the border: Research from the Mexican migration project. New York, NY: Russell Sage Foundation Publications.

Edelson, M. G., Hokoda, A., \& Ramos-Lira, L. (2007). Differences in effects of domestic violence between Latina and non-Latina women. Journal of Family Violence, 22(1), 1-10.

Equal Employment Opportunity Commission. (2014). Facts about retaliation. Retrieved from http://www.eeoc.gov/laws/types/facts-retal.cfm

Fisk, C. L., \& Wishnie, M. J. (2005). The story of Hoffman plastic compounds, Inc. v. NLRB: Labor rights without remedies for undocumented immigrants. In Labor law stories (pp. 399-438). New York, NY: Foundation Press.

Gleeson, S. (2010). Labor rights for all? The role of undocumented immigrant status for worker claimsmaking. Law and Social Inquiry, 35(3), 561-602. 
Granovetter, M. S. (1973). The strength of weak ties. The American Journal of Sociology, 78(6), 13601380.

Granovetter, M. S. (1995). Getting a job: A study of contacts and careers. Chicago, IL: University of Chicago Press.

Hall, M., \& Greenman, E. (2014). The occupational cost of being illegal in the United States: Legal status, job hazards, and compensating differentials. International Migration Review, (April). doi:10.1111/imre.12090.

Katz, V. (2014). Children as brokers of their immigrant families' health-care connections. Social Problems, 61(2), 194-215.

Legal Aid Society Employment Law Center. (2012). Undocumented workers: Employment rights/legal aid society - employment law center. Retrieved from http://www.las-elc.org/undocumentedworkers-employment-rights

Mattson, S., \& Ruiz, E. (2005). Intimate partner violence in the Latino community and its effect on children. Health Care for Women International, 26(6), 523-529. doi:10.1080/07399330590962627.

Menjivar, C. (2000). Fragmented ties: Salvadoran immigrant networks in America. Berkeley, CA: University of California Press.

Migration Policy Institute. (2015). Males per 100 females ratio among immigrants to U.S., 1870-2013. Retrieved from http://www.migrationpolicy.org/programs/data-hub/charts/males-100-femalesratio-among-immigrants-1870-present 
Mireles, G. F. (2013). Continuing La Causa: Organizing labor in California's strawberry fields (Vol. 28). Boulder, CO: Lynne Rienner Publishers.

National Employment Law Project. (2011). The U Visa: A potential immigration remedy for immigrant workers facing labor abuse. Washington, DC. Retrieved from http://www.nelp.org/page//Justice/2011/UVisa.pdf

Orellana, M. F. (2001). The work kids do: Mexican and Central American immigrant children's contributions to households and schools in California. Harvard Educational Review, 71(3), 366389.

Organista, K. C., \& Snowden, L. (2003). Latino mental health in California: Implications for policy. In D. Lo' pez \& A. Jiminez (Eds.), Latinos and public policy in California: An agenda for opportunity (pp. 217-239). Berkeley, CA: Berkeley Public Policy Press.

Orrenius, P. M., \& Zavodny, M. (2009). Do immigrants work in riskier jobs? Demography, 46(3), 535551.

Passel, J., \& Cohn, D. (2009). A portrait of the unauthorized migrants in the United States. Report. Washington, DC: Pew Hispanic Center. Retrieved from http://pewhispanic.org/files/reports/107.pdf

Passel, J. S., \& Taylor, P. (2010). Unauthorized immigrants and their U.S.-born children. Washington, DC: Pew Research Hispanic Trends Project. Retrieved from http://www.pewhispanic.org/2010/08/11/unauthorized-immigrants-and-their-us-bornchildren/

Pastor, M. (2009). Poverty, work, and public policy: Latino futures in California's new economy. In R. A. Gutierrez \& P. Zavella (Eds.), Mexicans in California: Transformations and challenges (pp. 15-35). Urbana, IL: University of Illinois Press. 
Pastor, Jr., M., \& Marcelli, E. A. (2000). Men N the Hood: Skill, spatial, and social mismatch among male workers in Los Angeles County. Urban Geography, 21(6), 474-476. doi:10.2747/02723638.21.6.474

Reynolds, J. F., \& Orellana, M. F. (2009). New immigrant youth interpreting in white public space. American Anthropologist, 111(1), 211-223.

Sanders, J. M., \& Nee, V. (1987). Limits of ethnic solidarity in the enclave economy. American Sociological Review, 52(6), 745773.

Schmidley, A. D., \& Gibson, C. (1999). Profile of the foreign-born population in the United States. Retrieved from http://www.census.gov/prod/99pubs/p23-195.pdf

Smith, S. S. (2010). A test of sincerity: How black and Latino service workers make decisions about making referrals. The ANNALS of the American Academy of Political and Social Science, 629(1), 30-52.

Talavera, V., Nunez-Mchiri, G. G., \& Heyman, J. (2010). Deportation in the U.S.-Mexico Borderlands: Anticipation, experience, and memory. In N. De Genova \& N. Peutz (Eds.), The deportation regime: Sovereignty, space, and the freedom of movement. Durham: Duke University Press.

Taylor, P., Lopez, M. H., Passel, J. S., \& Motel, S. (2011). Unauthorized immigrants: Length of residency, patterns of parenthood. Washington, DC: Pew Research Hispanic Trends Project. Retrieved from http://www.pewhispanic.org/2011/12/01/unauthorized-immigrants-length-of-residencypatterns-of-parenthood/

Villalon, R. (2010). Violence against Latina immigrants: Citizenship, inequality, and community. New York, NY: New York University Press. 
Waldinger, R. D., \& Lichter, M. I. (2003). How the other half works: Immigration and the social organization of labor. Berkeley, CA: University of California Press.

Zavella, P. (1987). Women's work and Chicano families: Cannery workers of the Santa Clara Valley. Anthropology of contemporary issues. Ithaca, NY: Cornell University Press.

Zavella, P. (2011). I'm neither here nor there: Mexicans' quotidian struggles with migration and poverty. Durham, NC: Duke University Press Books. 
Table 1. Distribution of Study Respondents.

\begin{tabular}{|c|c|c|c|c|c|c|}
\hline & All & NB & FB & FB_Cit & $\begin{array}{l}\text { FB_Non } \\
\text { Cit_LPR }\end{array}$ & $\begin{array}{c}\text { FB_Non } \\
\text { Cit_NonLPR }\end{array}$ \\
\hline Survey $-N=453$ & 453 & $122(.27)$ & $331(.73)$ & $89(.27)$ & $72(.22)$ & $170(.51)$ \\
\hline$\%$ married & .53 & .77 & .44 & .47 & .47 & .42 \\
\hline$\%$ who have children & .70 & .52 & .77 & .69 & .83 & .79 \\
\hline $\begin{array}{l}\mathrm{Y}-\% \text { whose children } \\
\text { are in school }\end{array}$ & .75 & .65 & .77 & .67 & .73 & .83 \\
\hline $\begin{array}{l}\text { Y - \% whose } \\
\text { dependent children } \\
\text { live in the United } \\
\text { States }\end{array}$ & .68 & .73 & .67 & .77 & .70 & .62 \\
\hline $\begin{array}{l}\mathrm{Y}-\% \text { whose } \\
\text { dependent children } \\
\text { live in country of } \\
\text { origin }\end{array}$ & .18 & - & .22 & .10 & .15 & .31 \\
\hline $\begin{array}{l}\% \text { who send money to } \\
\text { country of origin }\end{array}$ & .47 & - & .64 & .45 & .60 & .76 \\
\hline $\begin{array}{l}\% \text { who heard about } \\
\text { clinic from friend/ } \\
\text { family member }\end{array}$ & .26 & .16 & .31 & .22 & .18 & .40 \\
\hline $\begin{array}{l}\text { Follow-up interviews } \\
\qquad N=89\end{array}$ & 89 & $23(.26)$ & $66(.74)$ & $15(.23)$ & $16(.24)$ & $35(.53)$ \\
\hline$\%$ married & .47 & .61 & .42 & .40 & .44 & .43 \\
\hline$\%$ who have children & .70 & .43 & .79 & .80 & .88 & .74 \\
\hline $\begin{array}{l}Y-\% \text { whose children } \\
\text { are in school }\end{array}$ & .71 & .60 & .73 & .67 & .86 & .69 \\
\hline $\begin{array}{l}\text { Y - \% whose } \\
\text { dependent children } \\
\text { live at the United } \\
\text { States }\end{array}$ & .77 & .70 & .79 & .75 & .86 & .77 \\
\hline $\begin{array}{l}\mathrm{Y}-\% \text { whose } \\
\text { dependent children } \\
\text { live in country of } \\
\text { origin }\end{array}$ & .13 & - & .15 & .17 & .07 & .19 \\
\hline $\begin{array}{l}\% \text { who send money to } \\
\text { country of origin }\end{array}$ & .53 & - & .71 & .54 & .75 & .77 \\
\hline $\begin{array}{l}\% \text { who heard about } \\
\text { clinic from friend/ } \\
\text { family member }\end{array}$ & .33 & .26 & .35 & .40 & .31 & .34 \\
\hline
\end{tabular}

Notes: $\mathrm{All}=\mathrm{All}$ respondents; $\mathrm{NB}=$ native-born respondents; $\mathrm{FB}=$ foreign-born respondents; FB_Cit $=$ foreign-born respondents who are U.S. citizens; FB_NonCit_LPR $=$ foreign-born respondents who are not U.S. citizens and identify as legal permanent residents; FB_NonCit_NonLPR = foreign-bom respondents who are not U.S. citizens and do not identify as legal permanent residents (general proxy for undocumented). 